\title{
Pili (fimbriae) of Branhamella Species
}

Carl F. Marrs, Ph.D., Susan WelR, M.P.H. Ann Arbor, Michigan

PURPOSE: Pili (fimbriae) have frequently been found to be involved in the attachment of bacteria to mucosal epithelial cells, an important initial step in the disease process. The purpose of this study was to determine if Branhamella catarrhalis expresses type 4 pili.

MATERIALS AND METHODS: Piliated $B$. catarrhalis phenotypic characteristics of colony morphology, agar corrosion, twitching motility, competence for deoxyribonucleic acid (DNA) transformation, autoagglutination, and pellical formation were observed. DNA was isolated from Branhamella spp. and used in genomic Southern hybridizations with a Moraxella bovis pilin gene as a probe. Electron microscopy of negatively stained bacteria was carricd out to visualize pili.

RESULTS: $B$. catarrhalis has several (but not all) of the phenotypic characteristics that are related to the presence of type 4 (MePhe) pili in closely related Moraxella spp., including competence for DNA transformation, autoagglutination, pellicle formation, colony morphology, and pitting of agar. The one phenotype we have not found that is generally characteristic of type 4 piliated bacteria is twitching motility. Genomic Southern hybridization analysis using a cloned $M$. bovis $Q$ pilin gene as a probe reveals DNA homologous to the $Q$ pilin gene in $B$. catarrhalis, Branhamella ovis, Branhamella caviae, and Branhamella cuniculi. Examination of $B$. catarrhalis strain ATCC25240 by electron microscopy reveals two different kinds of pili. One kind appears similar to other type 4 pili, whereas a second class is short pili extending outward from all portions of the bacteria.

CONCLUSION: Phenotypic, electron-microscopic, and hybridization data are all consistent with type 4 pili being present on some $B$. catarrhalis strains.
From the University of Michigan School of Public Health, Ann Arbor, Michigan. This work was supported by United States Public Health Service grant BM-1 1 R01EY07125 from the National Eye Institute. Requests for reprints should be addressed to Carl F. Marrs, Ph.D., Department of Epidemiology, 109 Observatory Street Ann Arbor, Michigan 48109.
B acterial colonization of mucosal surfaces depends upon attachment of bacteria to mucosal epithelial cells, often mediated by means of pili or fimbriae [1], which are protein filaments that extend from the surface of the bacteria. Pili are composed of up to 10,000 polymerized protein subunits called pilins. There are many different types of pili as defined by morphology and by functions such as pellicle formation in broth, and there are many types of pilins as defined by sequence comparisons [2]. In addition to pilin, some pili have one or more minor structural components [3,4], and in the case of the Escherichia coli $\mathrm{P}$ and type 1 pili, one of these minor subunits is the actual adhesin responsible for the binding of the pilus to the receptor molecule present on the eukaryotic cell surface [4-6]. Not only can a single bacterial species have strains that express structurally different classes of pili [2,7], but a single bacterium may have the capacity to express more than one class of pili, either sequentially or simultaneously $[7,8]$.

Type 4 (MePhe) pili are present on a wide variety of pathogenic bacteria [9], including Moraxella bovis [10,11], Moraxella nonliquefaciens [12], Neisseria gonorrhoeae [13,14], Neisseria meningitidis [12], Bacteroides nodosus [15], Pseudomonas aeruginosa [16], and Vibrio cholerae [17]. As currently defined by Bergey's Manual of Systematic Bacteriology, the family Neisseriaceae contains the genera Neisseria, Moraxella, Acinetobacter, and Kingella [18]. A newly named genus, Psychrobacter [19], is also related to these genera. The genus Moraxella is subdivided into two subgenera, Moraxella and Branhamella [18]. B. catarhalis was previously classed as Neisseria catarrhalis [18].

Our laboratory has been studying the type 4 (MePhe) class of pili present on Moraxella sp. and those of related genera. These studies include the cloning of the pilin gene from $M$. bovis, which causes bovine keratoconjunctivitis, and the use of this pilin gene to examine the presence and genetic structure of type IV pilin genes in other members of the Neiseriaciae [10] (Marrs CF, Stevens SP, Wcir S, and Patel $\mathrm{P}$, manuscript in preparation). This article discusses what we know about the pili of Branhamella spp.

\section{TYPE 4 PILI IN MORAXELLA SPP.}

The type 4 pilins all share extensive amino-terminal amino acid sequence homology and, with the exception of $V$. cholerae, they all contain the modified amino acid $\mathrm{N}$-methylphenylalanine (MePhe) as the first residue of the mature protein $[9,13,20]$. That these conservations are important in a functional sense has been demonstrated by experiments in which $P$. aemuginosa bacteria processed and assembled $B$. nodosus pilins into pili structurally and immunologically indistinguishable from authentic $B$. nodosus pili $[21,22]$. Recently, similar experiments with our $M$. bovis pilin gene expressed in $P$. aeruginosa produced bacteria 
that actually had pili made up of both $M$. bovis pilin and $P$. aeruginosa pilin (Beard MKMG, Mattick JS, Moore LJ, et al, manuscript submitted). Functionally, the pili of $M$. bovis attach to the corneal epithelium and only piliated strains are able to infect experimentally exposed cattle [11,23]. Similarly, pili appear to promote the pathogenicity of $N$. gonorrhoeae by mediating their attachment to human host mucosal surfaces [24].

\section{MATERIALS AND METHODS}

\section{Bacterial Strains}

B. catarhalis strains ATCC8176, ATCC8193, ATCC25238, ATCC25239, and ATCC25240 were obtained from the American Type Culture Collection. $B$. catarrhalis strain B10 and Moraxella lacunata A'CC17956 were obtained from Dr. E. Juni, University of Michigan. M. bovis strain Epp63 was obtained from G.W. Pugh, Jr., Agricultural Research Service, Ames, Iowa. N. meningitidis strain M1080X was obtained from J.M. Koomey, University of Michigan.

\section{Laboratory Techniques}

Deoxyribonucleic acid (DNA) isolations and genomic Southern hybridizations were carried out as previously described [25]. All strains were grown on GC agar base (Difco Laboratories, Detroit, Michigan) with 1 percent IsoVitaleX (BBL Microbiology Systems, Cockeysville, Maryland). Two methods were used to assay for twitching motility, a hanging drop method of Depiazzi and Richards [26], and a plate method described by Henrichsen [27]. Electron microscopy of negatively stained bacteria was performed with a Zeiss EM-10CA transmission electron microscope using the procedures described by Hayat [28].

\section{PHENOTYPES OF PILIATED BACTERIA}

For $N$. gonorrhoeae, $M$. bovis, $M$. nonliquefaciens, and other bacteria [9], type 4 piliation is associated with a variety of phenotypes. These include being located on the poles of the bacteria [9], colony morphology and agar corrosion $[23,29]$, twitching motility $[30,31]$, competence for DNA transformation [32], autoagglutination, and pellicle formation on the surface of broth cultures [33]. Of these phenotypes, autoagglutination and pellicle formation are also associated with other classes of pili [2], and bacteria like Haemophilus influenzae can be competent for DNA transformation in the absence of pili [34].

We have observed several of these phenotypes usually associated with type 4 piliated bacteria in our studies of $B$. catarrhalis. The colonies are similar in appearance to $\mathrm{P}^{+} M$. bovis or $N$. yonorrhoeae. However, unlike $M$. bovis or $N$. gonorrhoeae, which show a readily detectable switch to a distinct colony type when they become non-piliated, we have yet to observe a $B$. catarrhalis with the normal nonpiliated colony morphology. Because we have not yet isolated a $B$. catarrhalis that lacks pili, it is not clear how many of the following phenotypes we observe are specifically associated with being piliated. For all strains we have examined, B. catarhalis colonies pit the agar, and the bacteria autoagglutinate and form pellicles in broth cultures. Most B. catarrhalis strains are capable of undergoing DNA transformation with related DNA $[35,36]$ and in fact the ability of $B$. catarrhalis to be transformed by $M$. nonliquefaciens DNA was the first evidence that it was related to Moraxella sp. [37]. Strain B10 is an exception, being non-competent for transformation despite forming a pellicle and having colonies that pit the agar and have $\mathrm{P}^{\prime}$ morphology. One characteristic type 4 piliation phenotype appears absent since two different twitching motility assays (described in Materials and Methods) were negative for every $B$. catarrhalis strain we tested, whereas the piliated controls from $M$. bovis, $M$. lacunata, and $N$. meningitidis all twitched. The presence of several phenotypes commonly correlated with type 4 piliation, coupled with the relatively close relationship between $B$. catarrhalis and several Moraxella spp. known to possess type 4 pili raiscd the question of whether $B$. catarrhalis might express type 4 pili.

\section{GENETICS OF TYPE IV PILI}

There are both similarities and differences in the genetic organization of type 4 pilin genes in different bacterial species. One similarity is that $P$. aeruginosa, $N$. gonorrhoeae, and $M$. bovis pilin genes all appear to use rpoN $\left(\sigma^{54}\right)$-dependent promoters [38,39]. In terms of numbers of pilin genes, $P$. aeruginosa strains only have a single copy of the pilin gene in each genome $[40,41]$, and most serotypes of $B$. nodosus also only have a single gene, but some are organized with the genes fim $\mathrm{A}$, fim $\mathrm{C}$, fim $\mathrm{Z}$ in order in the same orientation, where fim $\mathrm{A}$ and fim $\mathrm{Z}$ are both pilin genes [42]. $M$. bovis produces serologically different pilus types, and each strain is capable of producing one or the other of two pilus types $[33,43]$. $M$. bovis strain Epp63 expresses either Q pilin (formerly called beta) or I pilin (formerly called alpha). We have cloned and sequenced the $M$. bovis Q pilin gene [10], and shown that expression of either $Q$ or I pilin alternates via a 2-kilobase inversion of genomic. DNA [25]. N. gonorrhoeae, by contrast, contains multiple pilin gene loci in every strain and transitions from $\mathrm{P}^{+}$to $\mathrm{P}^{-}$and between different $\mathrm{P}^{+}$pilin types are often accompanied by chromosomal DNA rearrangements [44-46]. Strain MS11 can express at least seven different pilin genes [45], has two regions of its chromosome that act as pilin expression loci [45], and has many other sites that contain silent variant pilin sequences $[45,47]$. Most strains each have a single pilin expression locus and multiple silent variant pilin sequences [48]. All silent copies are only partial genes, lacking the common N-terminal coding sequence of pilin $[49,50]$. Antigenic variation from one $\mathrm{P}^{+}$type to another is a result of transformation of chromosomal DNA from other gonococci that have autolysed, followed by a recA ${ }^{+}$ dependent recombination event between silent copy donor DNA and the recipient expression locus [51]. Transitions from $\mathrm{P}^{+}$to $\mathrm{P}^{-}$sometimes involve deletions at the expression loci $[45,49]$, and sometimes involve sequences from silent copy loci recombining into the cxpression locus to produce pilin molecules, which are defective in assembly [52].

As part of a general survey of bacteria related to $M$. bovis that we are carrying out, we hybridized our $M$. bovis Q pilin gene probe to genomic Southern blots containing DNAs from a variety of organjsms. Figure 1 shows the hybridization patterns seen for four Branhamella spp. cleaved with EcoRI. Hybridization of the Q pilin probe to Branhamella ovis was moderately strong, about comparable with that seen with 

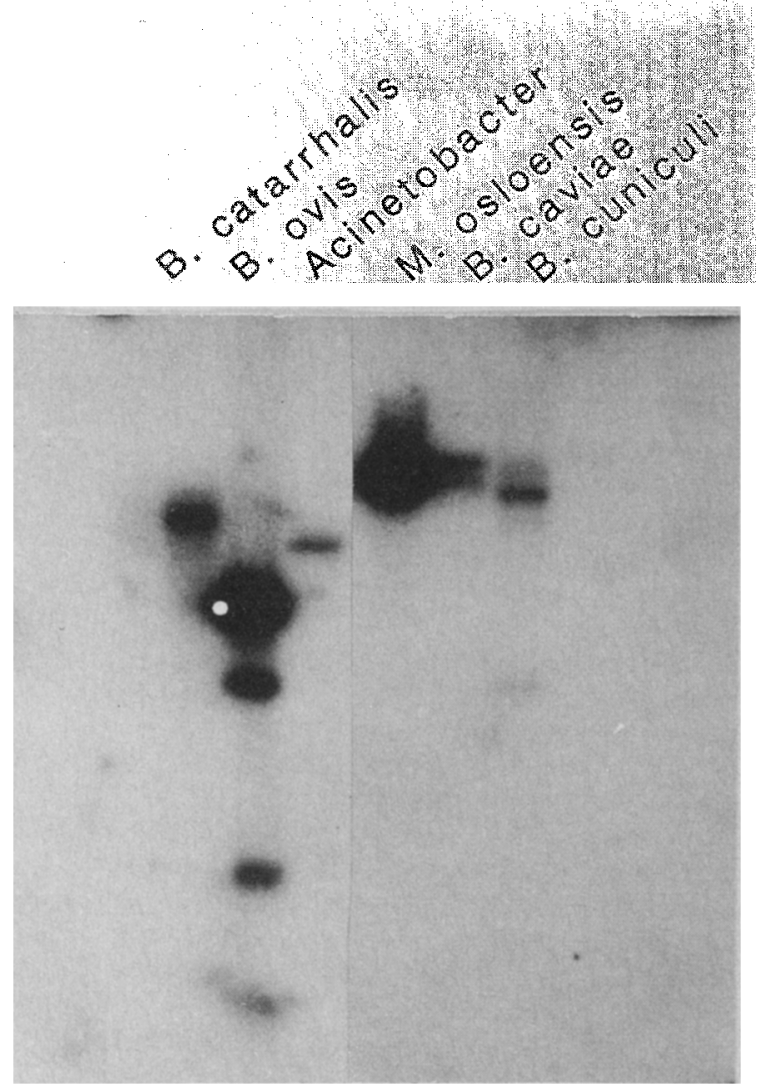

Figure 1. Hybridization using a M. bovis Q pilin gene probe to the following genomic DNAs cleaved with ECoRI: B. catarrhalis ATCC25238; B. ovis ATCC19575; Acinetobacter calcoaceticus ATCC15304; M. osloensis ATCC19962; B. caviae ATCC14659; B. cuniculi ATCC14688. Hybridization conditions were as described previously [44].

Moraxella osloensis (Figure 1), whereas B. catarrhalis, Branhamella caviae, and Branhamella cuniculi all hybridized at lesser, but clearly detectable levels. It is important to note that this hybridization data just tells us that DNA sequences similar to the $M$. bovis $\mathrm{Q}$ pilin gene are present in these bacteria. It does not tell us that type 4 pili are being expressed on the bacterial surface, or even guarantee that a complete pilin gene is present.

The observation that there are three bands of hybridization seen with $E$ coRI cleaved $B$. ovis DNA may mean that it contains more than one pilin gene. The fact that $B$. catarrhalis only has one band that hybridizes after $E c o$ RI cleavage does not rule out it having more than one gene or partial gene. In $M$. bovis Epp63, the complete and partial pilin gene sequences are close enough that they appear on the same EcoRI fragment. It does, however, appear to rule out multiple, distinct pilin gene loci as is found in N. gonorrhoeae [48].

\section{ELECTRON MICROSCOPIC EXAMINATION OF $B$. CATARRHALIS}

In electron-microscopic studies, type 4 pili can be observed as long filaments extending from the pole of the cell $[9,11]$. An example of normal type 4 piliated bacteria is shown in Figure 2, top left.
The only report of pili being observed on Branhamella spp. was that of Wistreich and Baker [53], who reported that they failed to see any pili on two American Type Culture Collection strains of $N$. catarrhalis (ATCC8176,ATCC8193). In contrast, they reported that one $N$. catarrhalis strain from the culture collection of the University of Southern California had two different pili types. Some organisms had numerous short pili emerging from their outer borders, with an occasional long pilus extending beyond them, whereas with other bacteria the longer type predominated. Our observations of $B$. catarrhalis strain using the electron microscope match these descriptions quite well. Figure 2, top right and lower left and right, shows our electron micrographs of $B$. $c a$ tarrhalis strain ATCC25240. In Figure 2, top right and lower left (at different magnification), can be seen examples of long, thin pili that appear very similar to the type 4 pili shown in Figure 2, top left. Figure 2, bottom right, shows the other class of short, thick pili with knobby ends that can be seen extending outward from all portions of the bacteria. Thus both phenotypic, electron-microscopic, and hybridization data all are in agreement that type 4 pili might be present on $B$. catarrhalis. The electron-microscopic data show that an additional, non-type 4 class of pili is also present. The relative roles of these two different classes of pili on the adherence properties and development of $B$. catarrhalis are exciting questions remaining to be explored.

\section{REFERENCES}

1. Beachey $\mathrm{EH}$ : Bacterial adherence: adhesin-receptor interactions mediating the attachment of bacteria to mucosal surfaces. J Infect Dis 1981; 143: 325-345.

2. Klemm P: Fimbrial adhesins of Escherichia coli. Rev infect Dis 1985; 7: 321-340. 3. Oudega $B$, de Graaf $M$, de Boer $L$, et al: Detection and identification of FaeC as a minor component of K88 fibrillae of Escherichia coli. Mol Microbiol 1989; 3: 645-652.

4. Lindberg F, Lund $B$, Johansson $L$, Normark S: Localization of the receptor-binding protein adhesin at the tip of the bacterial pilus. Nature 1987; 328: 84-87.

5. Minion FC, Abraham SN, Beachey EH, Goguen JD: The genetic determinant of adhesive function in type 1 fimbriae of Escherichia coli is distinct from the gene encoding the fimbrial subunit. J Bacteriol 1986; 165: 1033-1036.

6. Maurer L Orndorff PE: Identification and characterization of genes determining receptor binding and pilus length of Escherichia coli type 1 pili. J Bacteriol 1987; 169:640-645 7. Olsen $A$, Jonsson A, Normark S: Fibronectin binding mediated by a novel class of surface organelles on Escherichia coli. Nature 1989; 338: 652-655.

8. Archambaud M, Courcoux P, Labigne-Roussel A: Detection by molecular hybridization of pap, afa, and sfa adherence systems in Escherichia coll strains associated with urinary and enteral infections. Ann Inst Pasteur/Microbiol 1988; 139: 575-588.

9. Dalrymiple B, Mattick JS: Arl anralysis of the organizaliur and evolution of lype 4 limibrial (MePhe) subunit proteins. J Mol Evol 1987; 25: 261-269.

10. Marrs CF, Schoolnik G, Koomey JM, Hardy J, Rothbard J, Falkow S: Cloning and sequencing of a Moraxella bovis pilin genc. J Bacteriol 1985; 163: 132-139.

11. Ruehl WW, Marrs CF, Fernandez R, Falkow S, Schoolnik GK: Purification, characterization, and pathogenicity of Moraxella bovis pili. J Exp Med 1988; 168: 983-1002

12. Froholm $\angle O$, Sletten $K$ : Purification and $N$-terminal sequence of a fimbrial protein from Moraxella nonliquefaciens. FEBS Lett 1977; 73: 29-32.

13. Hermodson MA, Chen KCS, Buchanan TM: Neisseria pili proteins: amino-terminal amino acid sequences and identification of an unusual amino acid. Biochemistry 1978; 17 $442-445$.

14. Schoolnik GK, Fernandez R, Tai YT, Rothbard J, Gothschlich EC: Gonococcal pili: primary structure and receptor binding domain. J Exp Med 1984: 159: 1351-1370.

15. McKern NM O'Donnell IJ Inglis AS, Stewart DJ, Clark BL Amino acid sequence of pilin from Bacteroides nodosus (strain 198), the causative organism of ovine footrot. FEBS Lett 1983; 164: 149-153

16. Sastry PA, Pearlstur JR, Srrillie LB, Paranchych W: Arnirio acid sequerce of pilin isolated from Pseudomonas aeruginosa PAK. FEBS Lett 1983; 151: 253-256.

17. Taylor RK, Miller VL, Furlong DB, Mekalanos JJ: Use of phoA gene fusions to identify a pilus colonization factor coordinatcly regulated with cholera toxin. Proc Nat $\mid$ Acad Sci USA 1987; 81: 2833-2837.

18. Bovre K: Moraxella. In: Kreig NR, Holt JG, eds. Bergey's manual of systemic bacteriology. Vol. I. 1984; 296-303.

19. Juni E, Heym GA: Psychrobacter immobilis gen. nov., sp. nov.: genospecies composed of gram-negative, aerobic, oxidase-positive coccobacilli. Int J Syst Bacteriol 1986; 36: 388-391.

20. Elleman TC: Pilins of Bacteroides nodosus: molecular basis of serotypic variation and relationships to other bacterial pilins. Microbiol Rev 1988; 52; 233-247. 

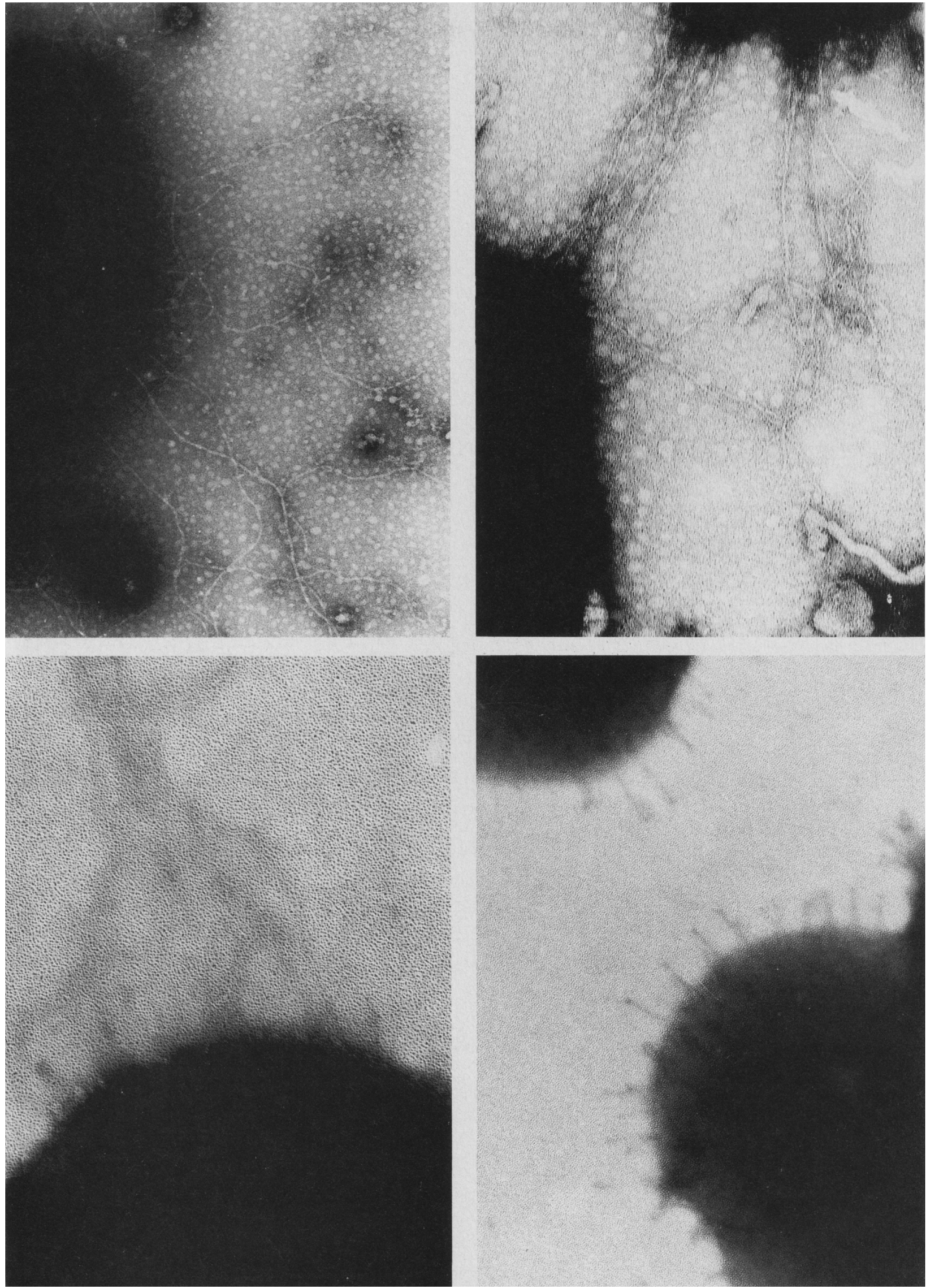

Figure 2. Top left, type 4 pili of M. bovis Epp63 $\mathrm{P}^{+}$, magnification $\times 94,000$; top right, long pili of $B$. catarrhalis ATCC25240, magnification $\times 140,000$; bottom left potential type 4 pili of $B$. catarrhalis ATCC25240, magnification $\times 110,000$; bottom right, potential non-type 4 pili of $B$. catarrhalis ATCC25240, magnification $\times 91,500$. 
21. Elleman TC, Hoyne PA, Stewart DJ, McKern NM, Peterson JE: Expression of pili from Bacteroides nodosus in Pseudomonas aeruginosa. J Bacteriol 1986; 168: 574-580.

22. Mattick JS, Biils MM, Anderson BJ, Dalrymple B, Mott MR. Egerton JR: Morphogenetic expression of Bacteroides nodosus fimbriae in Pseudomonas aeruginosa. J Bacteriol 1987; 169: 33-41.

23. Pedersen $\mathrm{KB}$, Froholm LO, Borne K: Fimbriation and colony type of Moraxella bovis in relation to conjunctival colonization and development of keratoconiunctivitis in cattle. Acta Path Microbiol Scand [B] 1972; 80: 911-918

24. Swanson J: Gonococcal adherence: selected topics. Rev Infect Dis 1983; 5 (suppl 4): S678-S684.

25. Marrs CF, Ruehl WW, Schoulnik GK, Falkow S: Pilin gene phase variation of Moraxella bovis is caused by an inversion of the pilin genes. I Bacteriol 1988; 170: 3032-3039. 26. Depiazzi LJ, Richards RB: Motility in relation to virulence of Bacteroides nodosus. Vet Microbiol 1985; 10: 107-116.

27. Henrichsen J: Bacterial surface translocation: a survey and a classification. Bacteriol Rev 1972; 36: 478-503.

28. Hayat MA: Basic techniques for transmission electron microscopy. New York: Academic Press, Inc., 1986; 232-234

29. Bovre K. Froholm LO: Variation of colony morphology reflecting fimbriation in Moraxella bovis and two reference strains of Moraxella nonliquefaciens. Acta Path Microbiol Scand [B] 1972; 80: 629-640.

30. Henrichsen J: Twitching motility. Ann Rev Microbiol 1983; 37: 81-93.

31. Henrichsen J, Froholm LO. Bovre K: Studies on bacterial surface translocation. Acta Path Microbiol Scand [B] 1972; 80; 445-452.

32. Bovre $K$, Froholm LO: Competence in genetic transformation related to colony type and fimbriation in 3 species of Moraxella. Acta Path Microbiol Scand [B] 1972; 80: 649659.

33. Sandhu TS, White FH, Simpson CF: Association of pilf with rough colony type of Moraxella bovis. Am J Vet Res 1974; 35: 437-439.

34. Goodgal SH: DNA uptake in Haemophilus transformation. Ann Rev Genet 1982; 16: 169-192.

35. Bovre K: Affinities between Moraxella spp. and a strain of Neisseria catarrhalis as expressed by transformation. Acta Path Microbiol Scand 1963; 58: 528.

36. Catiin BW, Cunningham LS: Genetic transformation of Neisseria catarrhalis by deoxyribonucleate preparations having different average base compositions. J Gen Microbiol 1964; 37: 341-352.

37. Catlin BW: Reciprocal genetic transformation between Neisseria catarmalis and Moraxella nonliquefaciens. J Gen Microbiol 1964; 37: 369-379.
38. Ishimoto K, Lory S: Formation of pilin in Pseudomonas aenuginosa requires the RpoN subunit of RNA polymerase. Proc Natl Acad Sci USA 1989; 86: 1954-1957.

39. Johnson $\mathrm{K}$, Lory S: Characterization of Pseudomonas aeruginosa mutants with altered piliation. J Bacteriol 1987; 169: 5663--5667.

40. Pasloske BL, Finlay BB, Paranchych W: Cloning and sequencing of the Pseudomonas aeruginosa PAK pilin gene. FEBS Lett 1985; 183: 408-412.

41. Sastry PA, Finlay BB, Pasloske BL, Paranchych W. Pearlstone JR, Smillie LB: Comparative studies of the amino acid and nucleotide sequences of pilin derived from $\%$ seudomo nas aeruginosa PAK and PAO. J Bacteriol 1985; 164: 571-577.

42. Mattick JS: The molecular biology of the fimbriae (pili) of Bacteroides nodosus and the development of a recambinant-DNA-based vaccine. In: Egerton JR, Yang WK, Riffkin GG, eds. Footrot and foot abscess of ruminants, Boca Raton, Florida: CRC Press, 1989; 195 218.

43. Lepper AWD, Barton IJ: Infectious bovine keratoconjunctivitis: seasonal variation in culture, biochemical and immunoreactive properties of Moraxella bovis isolated from the eyes of cattle. Aust Vet J 1987; 64: 33-39.

44. Bergstrom S, Robbins K, Koomey JM, Swanson J: Piliation control mechanisms in Neisseria gonorrhoeae. Proc Natl Acad Sci USA 1986; 83: 3890-3894.

45. Hagblom $P$, Segal $E$, Billyard $E$, So M: Intragenic recombination leads to pilus antigenic variation in Neisseria gonorrhoeae. Nature 1985; 315: 156-158.

46. Meyer TF, Mlawer N, So M: Pilus expression in Neisseria gonorrhoeae involves chromosomal rearrangement. Cell 1982; 30: 45-52.

47. Segal E, Billyard E, So M, Storzbach S, Meyer TF: Role of chromosomal rearrangement in $N$. gonorrioeae pilus phlase varialior. Cell 1985; 40: 293-300.

48. Swanson J, Bergstrom S, Barrera O, Robbins K, Corwin D: Pilus- gonococcal variants. J Exp Med 1985; 162: 729-744.

49. Haas $\mathrm{R}$, Meyer TF: The repertoire of silent pilus genes in Neisseria gonorrhoeae evidence for gene conversion. Cell 1986; 44: 107-115.

50. Segal E, Hagblom P, Seifert HS, So M: Antigenic variation of gonococcal pilus involves assembly of separated silent gene segments. Proc Natl Acad Sci USA 1986; 83: 217 2181.

51. Seifert HS, So M: Genetic mechanisms of bacterial antigenic variation. Microbiol Rev 1988; 52: 327-336.

52. Swanson J, Bergstrom S, Robbins K, Barrera O, Corwin D, Koomey JM: Gene conversion involving the pilin structural gene correlates with pilus t to pilus - changes in Neisseria gonorrhoeae. Cell 1986; 47: 267-276.

53. Wistreich GA, Baker RF: The presence of flmbriae (plll) in three species of Neisseria. J Gen Microbiol 1971; 65: 167-173. 